\title{
Biochemical and bacteriological profiles of asymptomatic bacteriuria among school children in Ago-Iwoye, Nigeria
}

\author{
Popoola, O. D., Agu, G. C., Oyeyipo, F. M., and *Thomas, B. T. \\ Department of Microbiology, Olabisi Onabanjo University, Ago Iwoye, Ogun State, Nigeria \\ *Correspondence to: benthoa2013@gmail.com; ORCID: http://orcid.org/0000-0003-0675-5749
}

\begin{abstract}
:
Background: Asymptomatic bacteriuria (ASB) in children is a predisposing factor to symptomatic urinary tract infection (UTI) that may be complicated by blood stream infections if not appropriately treated with resultant mortality or morbidity. The objectives of this study are to determine the prevalence of ASB, and evaluate both biochemical and bacteriological characteristics of urine samples of primary school pupils in Ago-Iwoye, Ijebu North Local Government Area (LGA), Ogun State, Nigeria.

Methodology: Three hundred and seventy-two (186 males and 186 females) apparently healthy (asymptomatic) pupils aged 2-16 years from four randomly selected primary schools in the LGA were screened for ASB. Clean catch specimen of midstream urine was collected from each subject. Biochemical analysis of the urine was performed with Combi 10 reagent strip. MacConkey and Cysteine Lactose Electrolyte Deficient (CLED) agar plates were inoculated with calibrated wireloop delivering $0.01 \mathrm{ml}$ of urine for aerobic culture at $37^{\circ} \mathrm{C}$ for 24 hours. Identification of significant bacteria on culture plates was done using conventional biochemical tests.

Results: The frequency of clear, slightly turbid and turbid urine were $31(8.3 \%), 99(26.6 \%)$ and 56 (15.1\%) respectively. All analyzed urine samples were alkaline and negative for ketone, glucose and blood, but contained protein in $230(61.8 \%)$, bilirubin in $184(49.5 \%)$, nitrites in $64(17.2 \%)$ and urobilinogen in $14(3.7 \%)$ subjects. The prevalence of significant bacteriuria was $11.8 \%$ (44 of 372 ) with $7.0 \%$ in males and $16.7 \%$ in females $(p=$ 0.0063). The frequency of bacteria isolated in descending order were Escherichia coli 61.4\%, Staphylococcus saprophyticus $61.4 \%$, Staphylococcus aureus $45.5 \%$, Bacillus subtilis $45.5 \%$, Enterococcus faecalis $43.2 \%$, Enterobacter spp 36.4\%, Serratia marscencen 31.8\%, Klebsiella pneumoniae 22.7\%, Proteus mirabilis $22.7 \%$ and Pseudomonas aeruginosa $20.5 \%$.

Conclusion: This result highlights the presence of significant bacteriuria among apparently healthy pupils in the study area, with higher prevalence in the female pupils. The apparent risk of developing symptomatic UTI with the attendant complications in these pupils should spur preventive education of parents/guardians and the general populace about this entity.
\end{abstract}

Keywords: Asymptomatic bacteriuria, S. saprophyticus, morbidity, prevalence, primary school pupils

Received April 11, 2019; Revised June 09, 2019; Accepted June 12, 2019

Copyright 2019 AJCEM Open Access. This article is licensed and distributed under the terms of the Creative Commons Attrition 4.0 International License (http://creativecommmons.org/licenses/by/4.0), which permits unrestricted use, distribution and reproduction in any medium, provided credit is given to the original author(s) and the source.

\section{Profils biochimiques et bactériologiques de la bactériurie asymptomatique chez des écoliers à Ago-Iwoye, Nigéria}

\author{
Popoola, O. D., Agu, G. C., Oyeyipo, F. M., et *Thomas, B. T. \\ Département de microbiologie, Université Olabisi Onabanjo, Ago-Iwoye, État d'Ogun, Nigéria \\ *Correspondance à: benthoa2013@gmail.com; ORCID: http://orcid.org/0000-0003-0675-5749
}

\section{Abstrait:}

Contexte: La bactériurie asymptomatique chez l'enfant est un facteur prédisposant à l'infection symptomatique des voies urinaires qui peut se compliquer d'infections du flux sanguin s'il n'est pas traité correctement avec la 
mortalité ou la morbidité qui en résulte. Les objectifs de cette étude sont de déterminer la prévalence d'ASB et d'évaluer les caractéristiques biochimiques et bactériologiques d'échantillons d'urine d'élèves du primaire à AgoIwoye, région du gouvernement local d'Ijebu North, État d'Ogun, au Nigéria.

Méthodologie: Trois cent soixante douze (186 garçons et 186 filles) des élèves apparemment sains (asymptomatiques) âgés de 2 à 16 ans de quatre écoles primaires sélectionnées au hasard dans la LGA ont été soumis à un dépistage du PNA. Des échantillons de capture d'urine à mi-parcours ont été recueillis chez chaque sujet. L'analyse biochimique de l'urine a été réalisée avec une bandelette de réactif Combi 10 . Des plaques de gélose MacConkey et Cysteine Lactose Déficient en électrolyte (CLED) ont été inoculées avec du fil électrolytique calibré, délivrant $0,01 \mathrm{ml}$ d'urine pour une culture aérobie à $37^{\circ} \mathrm{C}$ pendant 24 heures. L'identification des bactéries significatives sur des plaques de culture a été réalisée à l'aide de tests biochimiques classiques Résultats: La fréquence des urines claires, légèrement troubles et troubles était respectivement de 31 (8,3\%), 99 $(26,6 \%)$ et $56(15,1 \%)$. Tous les échantillons d'urine analysés étaient alcalins et négatifs pour la cétone, le glucose et le sang, mais contenaient des protéines chez $230(61,8 \%)$, de la bilirubine chez $184(49,5 \%)$, des nitrites chez $64(17,2 \%)$ et de l'urobilinogène chez $14(3,7 \%)$. La prévalence de la bactériurie significative était de $11,8 \%(44$ sur 372 ) avec $7,0 \%$ chez les hommes et $16,7 \%$ chez les femmes ( $p=0,0063)$. La fréquence des bactéries isolées par ordre décroissant était Escherichia coli 61,4\%, Staphylococcus saprophyticus 61,4\%, Staphylococcus aureus 45,5\%, Bacillus subtilis 45,5\%, Enterococcus faecalis 43,2\%, Enterobacter spp 36,4\%, Serratia marcescens $31,8 \%$, Klebsiella pneumoniae, Proteus mirabilis 22,7\% et Pseudomonas aeruginosa 20,5\%.

Conclusion: Ce résultat met en évidence la présence d'une bactériurie significative chez les élèves apparemment en bonne santé dans la zone d'étude, avec une prévalence plus élevée chez les élèves de sexe féminin. Le risque apparent de développer une infection urinaire symptomatique accompagnée des complications associées chez ces élèves devrait inciter à l'éducation préventive des parents / tuteurs et de la population en général sur cette entité.

Mots-clés: bactériurie asymptomatique, S. saprophyticus, morbidité, prévalence, élèves du primaire

\section{Introduction:}

The prevalence of significant bacteriuria and the consequences in children especially primary school pupils have been well documented $(1,2,3)$. Traditionally, the presence of bacteria in urine is said to be significant when the bacterial count is more than $10^{5}$ colony forming units (CFU) per millilitre of urine and such condition is not uncommon among public primary school pupils in Ogun State (4), considering their low socioeconomic status and prevailing poverty that prevents access to health care service and education.

The prevalence of significant bacteriuria is known to vary from place to place. In India, Kaushik and Chaudhary reported a low prevalence of $5 \%$ significant bacteriuria among primary school pupils (5) while Mzaki et al., and Ocokoru et al., in Tanzania and Uganda respectively reported high rates of $20.3 \%$ and $26.8 \%$ among primary school children $(6,7)$. In Nigeria, Aiyegoro et al., reported $11.9 \%$ rate among children in Ile-Ife (8) while Ogbukagu et al., reported a high prevalence rate of $17.6 \%$ among children in Anambra State (9). A previous study by Ayoade et al., among University students in Redemption camp in Ogun State, Nigeria, reported $25 \%$ rate among sampled subjects (10). Due to paucity of information on this entity in our environment, this study was conducted to determine the prevalence of ASB and evaluate biochemical and bacteriological characteristics of urine samples of apparently healthy primary school pupils in Ago-Iwoye, Ijebu-North Local Government area of Ogun State, Nigeria.

\section{Materials and methods:}

\section{Study setting, design and subjects}

This cross-sectional study was conducted in Ago Iwoye, Ijebu North Local Government Area (LGA) of Ogun State, Nigeria from March 2012 to March 2014. A total of 372 apparently healthy primary school pupils (186 males, 186 females) aged 2 to 16 years were enrolled into the study from 4 randomly selected public primary schools in the LGA. Informed consent of the parents/guardians of each pupil and the permission of each school head teacher were obtained. The study was approved by the Ethics Committee of the Ijebu North Local Government Area Council.

Children with fever and urinary symptoms such as dysuria, passage of dark urine, frequency, suprapubic or renal pain, facial or leg swellings, and those who have received antibiotics during 48 hours prior to sample collection were excluded.

\section{Sample collection}

A labeled, sterile wide mouth, screw cap plastic container of $20 \mathrm{ml}$ capacity was given to each parent/guardian with verbal and written instructions on the procedure for collecting mid-stream urine samples from the pupils. The samples were collected and immediately transported to the Microbiology 
Laboratory of the Olabisi Onabanjo University, Ago Iwoye, Ogun State, Nigeria for analysis.

\section{Macroscopy and biohemical analysis}

The urine samples were examined visually for turbidity (clear, slightly turbid or turbid) and appearance (clear, pale yellow, yellowish, amber or blood stained). The biochemical analysis was carried out using Combi 10 reagent strip (BHL Pharmaceuticals, United Kingdom) according to manufacturer's instructions. The parameters examined were $\mathrm{pH}$, specific gravity, ketones, protein, bilirubin, urobilinogen, glucose, nitrite, blood and leucocytes.

\section{Culture and isolation of bacteria}

MacConkey and Cysteine Lactose Electrolyte Deficient (CLED) agar plates (Merck, Germany) were inoculated using a calibrated sterile wire loop delivering $0.01 \mathrm{ml}$ of urine sample. The plates were incubated aerobically at $37^{\circ} \mathrm{C}$ for 24 hours. The number of colonies counted on each plate was multipled by a factor of 100 to estimate the colony forming units (CFU) per mililitre of urine, and significant bacteriuria was taken as $10^{5} \mathrm{CFU} / \mathrm{ml}$.

\section{Identification of bacteria}

Colonies from culture plates with significant bacteriuria were first Gram stained and bacteria identified to species level using conventional biochemical tests $(11,12)$. The Gram positive cocci were tested for catalase, coagulase, deoxyribonuclease, mannitol fermentation, aesculin hydrolysis, and sodium chloride utilization while the Gram positive bacilli were identified by spore staining, mannitol egg yolk fermentation and sugar fermentation tests. The Gram negative bacteria were biochemically identified using oxidase, indole, citrate utilization, motility, methyl red, voges proskaeur, and triple sugar iron tests scheme $(11,12)$.

\section{Antibiotic susceptibility testing}

Antibiotic susceptibility testing was done by the modified Kirby Bauer disk diffusion method (13) using the following antibiotic disks; cotrimoxazole $(25 \mu \mathrm{g})$, erythromycin $(5 \mu \mathrm{g})$, gentamicin $(10 \mu \mathrm{g})$, augmentin $(30 \mu \mathrm{g})$, streptomycin $(10 \mu \mathrm{g})$, tetracycline $(10 \mu \mathrm{g})$ and chloramphenicol $(10 \mu \mathrm{g})$ for Gram positive bacteria while augmentin $(30 \mu \mathrm{g})$, ofloxacin $(5 \mu \mathrm{g})$, gentamicin $(10 \mu \mathrm{g})$, nalixidic acid $(30 \mu \mathrm{g})$, nitrofuratoin $(200 \mu \mathrm{g})$, cotrimoxazole $(25 \mu \mathrm{g})$, amoxycillin $(25 \mu \mathrm{g})$ and tetracycline $(25 \mu \mathrm{g})$ were used for Gram negative bacteria. The diameter of zone of inhibition was interpreted as sensitive or resistance using the guidelines of CLSI (14).

\section{Statistical analysis}

Data were analysed with GraphPad InStat (GraphPad Software, Inc., San Diego). Association between variables was esablished using Chisquare test, with level of significance set at $p<0.05$

\section{Results:}

A high percentage of urine samples 93 (25\%) were pale yellow in colour, 54 (14.5\%) deep yellow, 32 (8.6\%) amber and 7 (1.8\%) clear, while none of the urine sample contained visible blood. In terms of consistency, 99 (26.6\%) urine samples were slightly turbid, 56 $(15.1 \%)$ were turbid while 31 (8.3\%) were clear. The chemical analysis of the urine samples showed 230 (61.8\%) were positive for protein, 184 (49.5\%) for bilirubin, 64 (17.2\%) for nitrite and 14 (3.7\%) for urobilinogen. Leucocyte was present in 158 (42.5\%) urine samples (Table 1 ).

Table 2 shows the prevalence of significant bacteriuria to be $11.8 \%$ (44 of 372 ) with $7.0 \%$ (13 of 186 ) in males and $16.7 \%$ (31 of 186$)$ in females $(p=0.0063)$. The frequency of each bacteria species isolated from urine in descending order as presented in Table 3 are Escherichia coli (61.4\%), Staphylococcus saprophyticus (61.4\%), Staphylococcus aureus $(45.5 \%)$, Bacillus subtilis $(45.5 \%)$, Enterococcus faecalis $(43.2 \%)$, Enterobacter spp (36.4\%), Serratia marscencen (31.8\%), Klebsiella pneumoniae (22.7\%), Proteus mirabilis $(22.7 \%)$ and Pseudomonas aeruginosa (20.5\%). 
Table 1: Macroscopic and biochemical analysis of urine samples from school children in Ago-Iwoye, Ogun State, Nigeria

\begin{tabular}{|c|c|c|}
\hline Parameters & Number & Percentage \\
\hline \multicolumn{3}{|l|}{ Appearance } \\
\hline Clear & 5 & 1.3 \\
\hline Pale yellow & 93 & 25.0 \\
\hline Deep yellow & 52 & 14.0 \\
\hline Amber & 222 & 59.7 \\
\hline Blood stained & 0 & 0 \\
\hline \multicolumn{3}{|l|}{ Consistency } \\
\hline Turbid & 146 & 39.2 \\
\hline Hazy & 199 & 53.5 \\
\hline Clear & 27 & 7.3 \\
\hline \multicolumn{3}{|l|}{$\mathrm{pH}$} \\
\hline acidic & 0 & 0 \\
\hline neutral & 0 & 0 \\
\hline alkaline & 372 & 100 \\
\hline \multicolumn{3}{|l|}{ Specific gravity } \\
\hline 1.000 & 240 & 64.5 \\
\hline 1.005 & 60 & 16.1 \\
\hline 1.010 & 20 & 5.3 \\
\hline 1.015 & 24 & 6.4 \\
\hline 1.020 & 28 & 7.5 \\
\hline \multicolumn{3}{|l|}{ Ketones } \\
\hline Positive & 0 & 0 \\
\hline Negative & 372 & 100 \\
\hline \multicolumn{3}{|l|}{ Protein } \\
\hline Present & 230 & 61.8 \\
\hline Negative & 142 & 38.2 \\
\hline \multicolumn{3}{|l|}{ Bilirubin } \\
\hline Positive & 184 & 49.5 \\
\hline Negative & 188 & 50.5 \\
\hline \multicolumn{3}{|l|}{ Urobilinogen } \\
\hline Positive & 14 & 3.7 \\
\hline Negative & 358 & 96.3 \\
\hline \multicolumn{3}{|l|}{ Glucose } \\
\hline Positive & 0 & 0 \\
\hline Negative & 372 & 100 \\
\hline \multicolumn{3}{|l|}{ Nitrite } \\
\hline Positive & 64 & 17.2 \\
\hline Negative & 308 & 82.8 \\
\hline \multicolumn{3}{|l|}{ Blood } \\
\hline Positive & 0 & 0 \\
\hline Negative & 372 & 100 \\
\hline \multicolumn{3}{|l|}{ Leukocytes } \\
\hline Positive & 158 & 42.5 \\
\hline Negative & 214 & 57.5 \\
\hline
\end{tabular}

Table 2: Significant bacteriuria among primary school children in Ago Iwoye in relation to gender

\begin{tabular}{|c|c|c|c|}
\hline \multirow[t]{2}{*}{ Significant bacteriuria } & \multicolumn{2}{|c|}{ Gender } & \multirow[t]{2}{*}{ Total (\%) } \\
\hline & Male (\%) & Female (\%) & \\
\hline Positive & $13(7.0)$ & $31(16.7)$ & $44(11.8)$ \\
\hline Negative & $173(93.0)$ & $155(83.3)$ & $328(88.2)$ \\
\hline Total & 186 & 186 & 372 \\
\hline
\end{tabular}


Table 3: Distribution of bacterial uropathogens among primary school pupils in Ago-Iwoye in relation to gender

\begin{tabular}{cccc}
\hline \multicolumn{1}{c}{ Bacteria } & Male & Female & Total (\%) \\
\hline Gram positive & & & 27 \\
Staphylococcus saprophyticus & 9 & 18 & 20 \\
Staphylococcus aureus & 7 & 13 & 19 \\
Enterococcus faecalis & 7 & 12 & 20 \\
Bacillus subtilis & 6 & 14 & 27 \\
Gram negative & 9 & 18 & 16 \\
Escherichia coli & 5 & 11 & 14 \\
Enterobacter spp & 5 & 9 & 10 \\
Kerratia marcescens & 2 & 6 & 10 \\
Proteus mirabilis & 4 & 6 & 172 \\
Pseudomonas aeruginosa & 3 & 115 & \\
\hline Total & 57 & 6 & \\
\hline The isolates were counted per urine sample and all urine yielded polymicrobial growth. The total number of isolates was calculated by adding up the \\
number of time each isolate was recovered from the 44 subjects with significant bacteriuria
\end{tabular}

\section{Discussion:}

The prevalence rate of $11.8 \%$ for significant bacteriuria in our study compares favorably with the $11.9 \%$ rate reported by Aiyegoro et al., among children in Ile-Ife (8) which is a region in the same southwestern geographical zone as our study area. In addition, the macroscopic features of urine reported in our study are similar to those reported by Dada and Aruwa in Akure, southwest Nigeria (3). The rate in our study is however less than $17.6 \%$ rate reported by Ogbukagu et al., in southeastern zone of Nigeria (9) and also less than 25\% rate reported in a previous study by Ayoade et al., among university students in Ogun State (10). This is not unexpected as rates of ASB tend to vary from region to region, and are generally higher among young adults in reproductive age group like the university students in the study by Ayoade et al., (10). The significantly higher prevalence of ASB in females is our study is in line with what has been generally established. The female urinary system is in close proximity with the anus and vaginal, and coupled with the shorter female urethra, this encourages colonization and ascending infection from normal vaginal and anal flora.

The findings on chemical analysis of the urine may reveal underlying pathology when certain analytes such as glucose, ketones or blood, which are usually not present in urine of normal persons, are found. In this study however, none of the urine samples from the children contained glucose, ketone or blood. While some authors have reported presence of blood in urine (haematuria) as a common occurrence without associated disease process within the urinary tract, others have emphasized haematuria as a sign of urinary tract pathology from infections, stones or cancer $(15,16)$. The presence of blood in urine samples (terminal haematuria) is however an important marker for the diagnosis of urinary shistosomiasis in an endemic region (17). The fact that none of the urine samples in our study contained blood is an indication that the studied population had no underlying pathology especially related to schistosomiasis $(18,19,20)$.

The finding of $E$. coli as the most prevalent uropathogen in significant bacteriuria in our study agrees with reports of previous studies $(21,22)$, and the higher prevalence in females is similar to other reports (23). This observation is also in agreement with the study of Abdul et al., who reported $E$. coli (a human faecal flora that inhabits the colon as an inocuous commensal) to be the most prevalent facultative gram negative bacillus causing UTI in their study (24). The isolation of other members of the family enterobacteriaceae such as Enterobacter spp, S. marcescens, $K$. pneumoniae and $P$. mirabilis in urine in our study is also due to the fact that these organisms are frequently present in small number as normal flora of the intestine from where they can colonize anterior urethra and be present in significant number in voided urine (25). Similary, Ps. aeruginosa may be present as normal flora of the intestine and anterior urethra, however it is usually a cause of hospital acquired UTI particularly in patients with immunosuppression, malignancy, cystic fibrosis, burns and traumatic wound injuries (26).

Staphylococcus saprophyticus was the most prevalent Gram positive uropathogen in ASB occurring with same frequency as $E$. coli in our study. This finding agrees with the study by Ranjbar et al., (23) who reported $S$. saprophyticus as the most prevalent, but differs from those of Forouzan et al., who reported $S$. aureus as the most prevalent Gram 
positive uropathogen in their study (27). S. saprophyticus has long been recovered as normal flora of urogenital tract of women (28) but it has also been described as the second most common cause of uncomplicated acute UTI after $E$. coli in young sexually active women in the western world (29). The high frequency of $S$. saprophyticus isolation in both male and female pupils with ASB in this study implies that this Gram positive pathogen with others such as $S$. aureus and Enterococcus facecalis, should be considered as significant pathogens when investigating bacteria agents of UTI in our region.

\section{Conclusion:}

Results of the study highlights the presence of significant bacteriuria, predominantly caused by $E$. coli and $S$. saprophyticus, among apparently healthy pupils in the study area, with higher prevalence in the female pupils. The apparent risk of developing symptomatic UTI with its attendant complications in these pupils should spur preventive education of the parents/guardians and the general populace of the possible menace of this entity.

\section{References:}

1. Beetz, R. "May we go on with antibacterial prophylaxis for urinary tract infections?" Pediatr Nephrol. 2006; 21 (1): 5-13

2. Frank-Peterside, N., and Eton, E. "Asymptomatic Bacteriuria among Pupils of the University of PortHarcourt Demonstration Primary School, RiversState, Nigeria". Asian J Microbiol Biotechnol Env Sci. 2007; 9 (3): 543-546.

3. Dada, E. O., and Aruwa, C. E. Asymptomatic Bacteriuria Prevalence among Primary School Children in the Federal University of Technology, Akure (Futa), Ondo State, Nigeria. J Appl Life Sci Int. $2016 ; 4$ (4): 1-8.

4. Najar, M. S., Saldanha, C. L., and Banday, K. A. Approach to urinary tract infections. Indian J Nephrol. 2009; 19 (4): 129-139.

5. Kaushik, V., and Chaudhary, S. R. Study for prevalence of urinary tract infection (UTI) in febrile children and to assess the validity of microscopic urine analysis in the diagnosis of UTI. Int J ContemporMed Res. 2017; 4 (4): 826-829

6. Msaki, B. P., Mshana, S. E., Hokororo, A., Mazigo, H. D., and Morona, D. Prevalence and predictors of urinary tract infection and severe malaria among febrile children attending Makongoro health centre in Mwanza city, North-Western Tanzania. Arch Publ HIth. 2012; 70 (1): 1-8.

7. Ocokoru, C., Anguyo, R., Onzima, D. D. M., Govule, P., and Katongole, S. P. Prevalence and Drug Susceptibility of Isolates of Urinary Tract Infections Among Febrile Under-Fives in Nsambya Hospital, Uganda. Open Sci J Clin Med. 2015; 3 (6): 199-204

8. Aiyegoro, O. A., Igbinosa, O. O., Ogunmwonyi, I. N., Odjadjare, E. E., Igbinosa, O. E., and Okoh, A.
I. Incidence of urinary tract infections (UTI) among children and adolescents in Ile-Ife Nigeria. Afr] Microbiol Res. 2007; 013-019.

9. Ogbukagu, C. M., Anakwenze, V. N., Ekwealor, C. C., Ezemba, C. C., and Ekwealor, I. A. Incidence of Urinary Tract Infections (UTI) amongst Patients Attending Primary Health Centres in Anambra State. Adv Microbiol. 2016; 6: 537-547.

10. Ayoade, F., Moro, D. D., and Ebene, O. L. Prevalence and Antimicrobial Susceptibility Pattern of Asymptomatic Urinary Tract Infections of Bacterial and Parasitic Origins among University Students in Redemption Camp, Ogun State, Nigeria. Open J Med Microbiol. 2013; 3: 219-226.

11. Fawole, M. O., and Oso, B. A. Laboratory manual of microbiology. 5th edition. Ibadan: Spectrum Books Ltd 2001; 15-22.

12. Cheesbrough, M. C. District laboratory manual in tropical countries. Part 2 ( $2^{\text {nd }}$ edition). Cambridge: Cambridge University Press 2006

13. Bauer, A. W. Kirby, W. M., Sherris, J. C., and Turck, M. Antibiotic susceptibility testing by a standardized single disk method. Am J Clin Pathol. 1966; 45 (4): 493-496.

14. Clinical and Laboratory Standard Institute. Performance standards for antimicrobial disk susceptibility tests. NCCLS documents M 100 S15, Wayne, PA, USA, 2013.

15. Fitzwater, D. S., and Wyatt, R. J. Hematuria. Pediatrics Rev. 1994; 15: 102-105.

16. Esmaeili, $M$. Antibiotics for causative microorganisms of urinary tract infections. Iranian J Pediatr Infect. 2005; 15: 163-183.

17. Mostafa, M. H., Sheweita, S. A., and O'Connor, P. J. Relationships between schistosomiasis and bladder cancer. Clin microbial Rev. 1999; 12: 97111

18. Chitsulo, L., Engels, D., Montresor, A., and Savioli, L. "The global status of schistosomiasis and its control. Acta Trop. 2000; 77: 41-51.

19. Ojo, D. A., Osuolale, K. O., and Mafiana, C. F. Prevalence of urinary tract infections among students in a Nigerian university. Proceedings of International Conference on Science and National Development 2004; 120-23.

20. Biu, A. A., Nwosu, C. O., and Akuta, A. The incidence of human Schistosomiasis in Maiduguri, northern Nigeria. Biosci Res. Comm. 2000; 12 (1): 9-11

21. Ossai, O. P., Dankoli, R., Nwodo, C., et al. Bacteriuria and urinary schistosomiasis in primary school children in rural communities in Enugu State, Nigeria. Pan Afr Med J. 2014; 18 (1): 15.

22. Oluyemi, E. D., Fred, C. A., and Opeyemi, Z. L. Bacteriuria among primary and secondary school pupils in Akure-North Local Government Area of Ondo State, Nigeria. Acta Clinical Croat. 2012; 51: 379-385.

23. Ranjbar, R., Haghi-Ashtiani, M. T, Jonaidi, J. N., and Abedini, M. The Prevalence and Antimicrobial Susceptibility of Bacterial Uropathogens Isolated from Pediatric Patients. Iranian J Publ Hlth. 2009; 38 (2): 134-138

24. Abdul, R., Shariff, V. A., Suchitra, S. M., Taruna, Y., and Radhakrishma, $M$. The Antibiotic Susceptibility Patterns of Uropathogenic Escherichia coli with Special Reference to the Fluroquinolones. J Clin Diagn Res. 2013; 7 (6): 1027-1030.

25. Brooks, G. F., Butel, J. S., and Morse, S. A. Cell Structure: In: Jawets, Melnick and Adelberg's Medical Microbiology 22nd ed. Lange Medical Books/McGraw-Hill USA 2001; 7- 37.

26. Karakoc, B., and Gerceker, A. A. In-Vitro Activities of Various Antibiotics Alone and in Combination 
With Amikacin Against Pseudomonas aeruginosa. Int J Antimicrob Agents. 2001; 18: 567 - 570.

27. Forouzan, M., Zahra, A., and Amir, B. Prevalence and Antimicrobial Susceptibility Patterns of Uropathogens among Patients Referring to Valieasr Laboratory in Najafabad, Isfahan, Iran. Middle-East J Sci Res. 2013; 13 (1): 85-90
28. Rupp, M. E., Soper, D. E., and Archer, G. L. Colonization of the female genital tract with Staphylococcus saprophyticus. J Clin Microbiol. 1992; 30: 2975-2979

29. Raz, R., Colodner, R., and Kunin, C. M. Who are you-Staphylococcus saprophyticus? Clin Infect Dis. 2005; 40: 896-898 